Alexsandr A. Burmaka', Tatyana N. Govorukhina ${ }^{2}$,

DOI: $10.25045 /$ jpit.v10.i2.03

Dmitriy V. Krupennikov ${ }^{3}$

${ }_{1,2}^{1,2}$ Southwest State University, Kursk, Russia

${ }^{3}$ London express school of English

kkstu-bmi@yandex.ru, ${ }^{2}$ govtn@mail.ru, ${ }^{3}$ krupen_92@mail.ru

\title{
THE PATTERNS OF ANALOG AND DIGITAL TRANSFORMATIONS FOR VIDEO PULSE SEQUENCES UNDER PREDEFINED UNCERTAINTY CHARACTERISTICS OF THE INPUT IMPACT
}

\author{
Received: 21.12.2018 Revised: 27.02.2019 Accepted: 10.03.2019
}

The analysis of analog and digital transformations for the sequences of video signals which enter the information measuring system (IMS) as an input impact (which is an additive compound of practical signals and noises) was held. The primary signal processing methods in the receiving channel of the IMS which allows receiving authentic metering information about temporal and energy parameters of signals in the present time scale, and moreover, to minimize error in their metering under conditions of predefined uncertainty about the input impact qualities are displayed in the article. The practicability of functional separation into temporal and energy branches of the IMS's objective function which points at the reduction of their analog and digital transformation's influence on nonlinear phenomena that emerge in the IMS's receiving channel subsystem was substantiated.

Keywords: analog and digital transformation, evaluation of video signals' parameters.

\section{Introduction}

The receiving channel of the IMS interacts with the video signals against the background of additive noise interference and executes the following basic functions [1,2]:

- detection of the video pulses in the additive compound with noise interferences under predefined uncertainty of their characteristics $[2,3]$;

- filtering of signals and noises;

- analog and digital transformation of video signals into practical shape towards subsequent receiving of metering information.

This subset of functions, being a compound of IMS' objective function, can be described algorithmically with the help of controllers as directed actions in the following enumeration:

$E_{a}$ is analog transformation of signals;

$E_{H}$ is detection of the practical signals in the input impact $\xi(t, \lambda, S)$, where $\lambda$ is the intensity of the input impact stream, $S$ are practical signals, $t$ is the time interval;

$E_{f}$ is filtration of signals;

$E_{J}$ is informational transformation of the current information;

$E_{3 a}$ is input impact delay;

$E_{d f}$ is input impact differentiation altogether with signals which are standardized by amplitude and duration;

$E_{u a}$ is digital-to-analog transformation (DAT);

$E_{a y}$ is analog-to-digital transformation (ADT);

$E_{a c}$ is temporal selection of signals;

$E_{a d}$ is analog and digital transformation of signals;

$E_{u b}$ is digital transformation of time intervals;

$E_{u \ni}$ is digital transformation of the energy parameters and signal characteristics;

$E_{\gamma}$ is arrival at a decision about current evaluation of the time intervals. 
The cited complex of controllers is the basis for the formation of the described processes of analog and digital transformation of signals.

\section{Task setting}

The objective function (OF) of the IMS' receiving channel can be presented as two interconnected branches: frequency/time and energy; each of which is described by the corresponding complex of the controller equations.

Frequency/time branch embodies the following functions:

- adjustment of the IMS' receiving channel with the input impact characteristics $\xi(t, \lambda, S)$ in the bandwidth $\Delta F_{o \sigma}$, i.e.

$$
U_{1}=E_{f} E_{a}\left[\xi(t, \lambda, S), \Delta F_{o \sigma}\right] ;
$$

- matching the detection processes with metering the current value of the video signals parameters in time:

$$
\left.U_{2}=E_{3 a}[\xi(t, \lambda, S)]=\xi\left(t_{i}-\tau_{3}, \lambda, S\right)\right],
$$

where $\tau_{3}$ is delay of the input impact in time;

- segregation of the detected signals from the input impact using the temporal strobing, i.e.

$$
U_{3}=E_{a c}\left(U_{2}\right)=E_{a c}\left[\xi\left(t_{i}-\tau_{3}\right), \lambda, S_{i}\right]
$$

- analog and digital transformation of the video signals by duration, their standardization by amplitude $A(S)$ :

$$
U_{4}=E_{a d}\left(U_{3}\right)=E_{a d}\left[S\left(t_{i}-\tau_{3}\right), A(S)=\text { const }\right] ;
$$

- digital transformation of the parameters which were predefined by the time intervals:

$$
U_{5}=E_{u b}\left(U_{4}\right)=E_{u b} E_{a d}\left[S\left(t_{i}-\tau_{3}\right), A(S)=\text { const }\right],
$$

parametric quantities which were received through the digitization of the analog quantities in the real time with the pace of $\Delta t_{3}$ [4] are being used as temporal intervals, i.e.

$$
U_{6}=\left\{\begin{array}{l}
E_{\gamma}\left[U_{s}\left(\tau_{H}\right)\right]=\hat{\tau}_{U}\left(N_{1} \cdot \Delta t_{\ni}\right) ; \\
E_{\gamma}\left[U_{s}\left(T_{h}\right)\right]=\hat{T}_{h}\left(N_{2} \cdot \Delta t_{\ni}\right) ; \\
E_{\gamma}\left[U_{s}\left(\tau_{k}\right)\right]=\hat{\tau}_{U}\left(N_{3} \cdot \Delta t_{\ni}\right) ; \\
E_{\gamma}\left[U_{s}\left(T_{c}\right)\right]=\hat{T}_{c}\left(N_{4} \cdot \Delta t_{\ni}\right),
\end{array}\right.
$$

where the serial statistics are:

$\hat{\tau}_{U}$ - impulses' duration; $\hat{T}_{U}$ - value of their interval's consecution; $\hat{\tau}_{k}$ - value of the interpulse intervals; $\hat{T}_{c}$ - quantity for the consecution period of the series of impulses.

Energy branch of the OF embodies:

- detection of the video pulses in the input compound, i.e.

$$
U_{7}=E_{H}\left[\xi(t, \lambda, S), \Delta F_{o \sigma}\right]=S_{i r}\left(t-t_{i}, \lambda_{r}, a \Rightarrow \Pi_{\text {nоp }}\right),
$$

where $S_{i r}$ is an $i$-signal of the $r$-object with the intensity of $\lambda_{r}$ and the parameter of «a», $a \in A(S)$, i.e., the amplitude which exceeds the cut-off level $\Pi_{\text {nор }}$;

- differentiation of the input impact $\xi(t, \lambda, S)$, which is being used as $\dot{\xi}(t, \lambda, \dot{S})$ for the formation of the cut-off level $\Pi_{n o p}^{*}[2]$ : 


$$
U_{8}=E_{d f}\left[\xi(t, \lambda, S), \Delta F_{o \sigma}\right]
$$

- differentiation of the standardized signals by amplitude and duration on the predefined level:

$$
U_{9}=E_{d f}\left(U_{4}\right)=E_{d f} \cdot E_{a d}\left[S\left(t_{i}-\tau_{3}\right)\right]
$$

- analog and digital transformation of the signals' amplitude:

$$
U_{10}=E_{a u}\left(U_{3}\right)=E_{a u} \cdot E_{a c}\left[\xi\left(t_{i}-\tau_{3}\right), \lambda, S\right] .
$$

Therefore the system of the controller equations could be used for algorithmization and physical interpretation of the OF functions' complex through appropriate processes.

\section{Task solution}

Since the implementation of detecting functions is primary (figure1, design a $\&$ b) as much as the following standardization of the impulse signals by amplitude and duration (figure 1, design c) it means that in accordance with the controller equations 5, 6 and 11

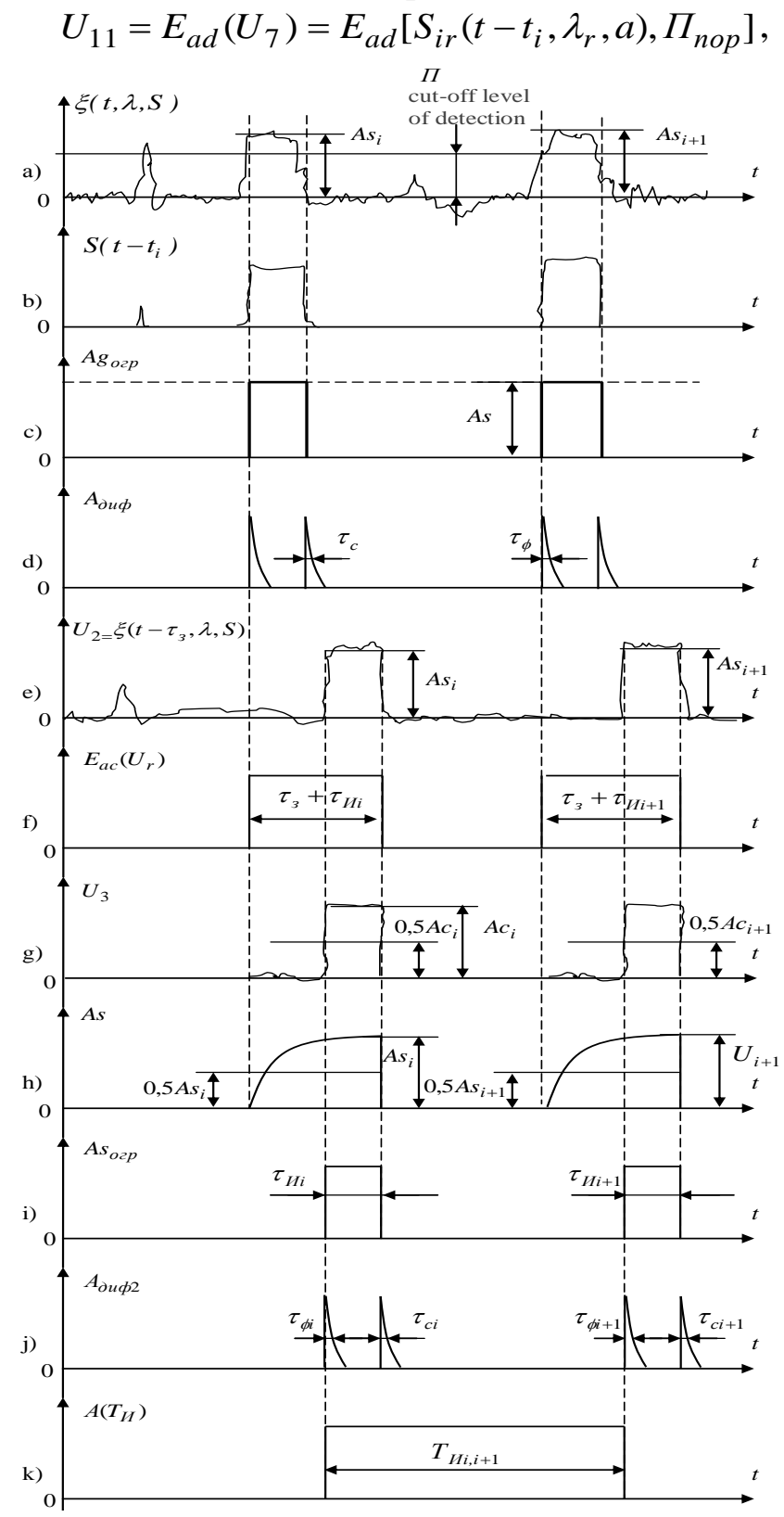

Figure 1. Comprises of designs that illustrate the processes for detection and transformation of the video signals

The structural subpattern for the video pulse detection can be presented the way it is in the 
figure 2 .

The differentiator, being a part of the structural subpattern for the video pulse detection (figure 2), embodies the formation of command control for the process of temporal selection of the impulse signals out of the compound $\xi\left[\left(t, \lambda_{r}, S_{i r}\right), \Delta F_{o \sigma}^{(r, r+1)}\right]$ in accordance with the controller equation 7.

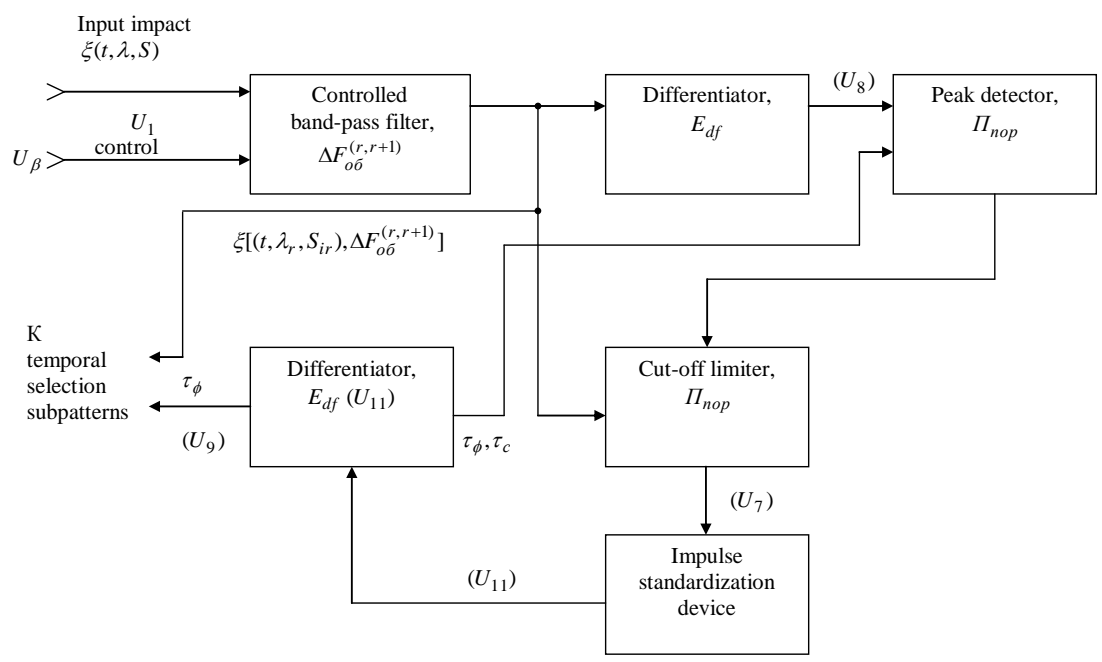

Figure 2. The structural subpattern for the detection of the video pulses

As a result the command impulses of short duration are being formed in the output of the differentiator (figure1, design d) and they coincide with the front (duration $\tau_{\phi}$ ) and the decline (duration $\tau_{c}$ ) by time position, as well as with their help one can guarantee the linking of the subpattern for detection with the one for the temporal selection of video pulses as shown in the figure 3.

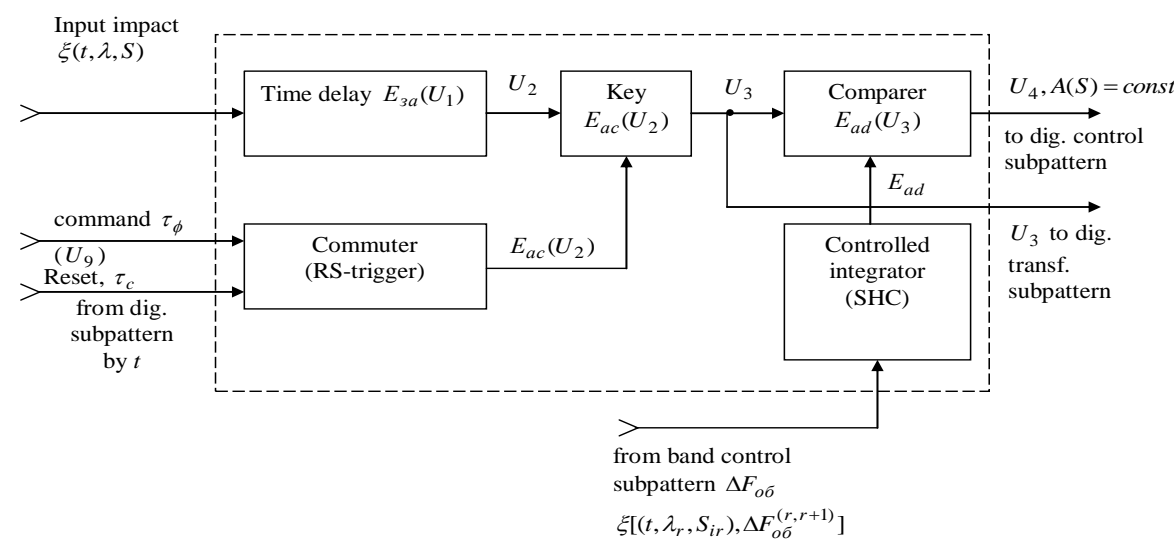

Figure 3. The structural subpattern for the temporal selection of the video pulses

The delay $\tau_{3}$ of the input impact $\xi(t, \lambda, S)$ causes the processes of detection to adjust with analog and digital transformation of the video pulses in time. The detachment from the compound $\xi(t, \lambda, S)$ of delayed video pulses (figure 1, design e) is carried out through the command $\tau_{\phi}$ (figure 2) that initiates the controller $E_{a c}$ (figure 1, design f) which detaches the detected video pulses through strobing the input compound (key, figure 3) within the duration of the temporal strobe which is $\tau_{c m p}=\tau_{3}+\tau_{u_{i}}$ (figure1, design f), in accordance with the controller equation (2) as shown in the figure 1 design $\mathrm{g}$.

After that one does the standardization of the impulses by amplitude and duration on the assigned level in accordance with the controller equation (3) and using controlled integration (sample and hold circuit (SHC), figure 3). The characteristic of the amplification path (which 
precedes the IMS) in standardization by amplitude of the impulse $S_{i r}$ is taken into consideration and so are the conditions for spreading the signals in the external environment (direct visibility, tropospheric spreading etc). The duration of the impulse for the linear path, in particular, is being stardardized (defined) on the level of 0,5 As, i.e.

$$
a_{k}\left(S_{i r}\right)=\tau_{u}\left(0,5 A s_{i r}\right)
$$

The final standardization of the impulse $S_{i r}$ by amplitude and duration is being processed by comparer (figure 3 ) from which output the impulses (figure 1, design i) proceed after the analog and digital transformation as the strobe intervals to the input of the digitization control subpattern by time (what is structurally presented in the figure 4 ).

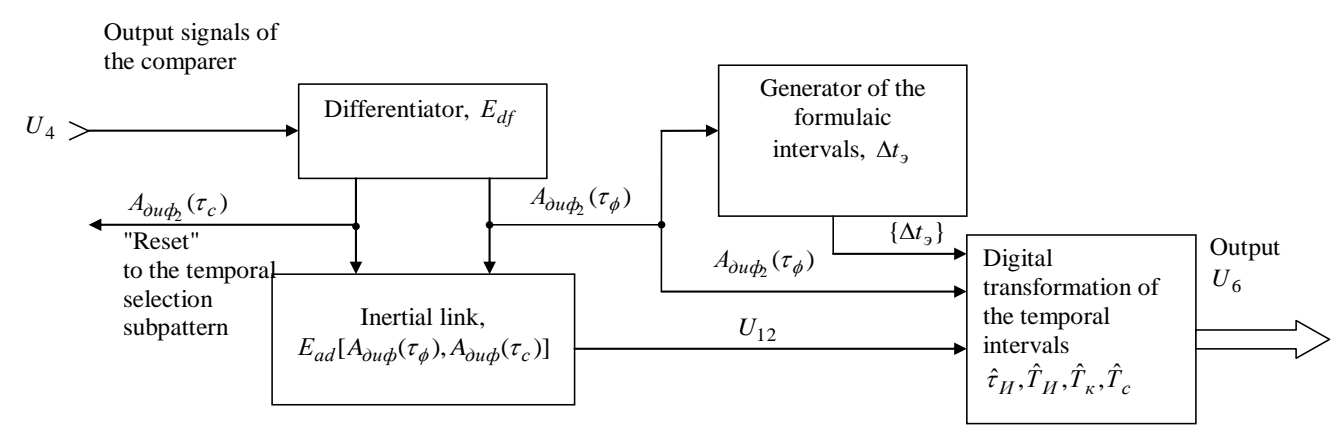

Figure 4. The digitization control subpattern by time

The output signals of the comparer (figure 1, design i) proceed to the differentiator (figure 4) which forms the short duration impulses $\tau_{\phi}$ and $\tau_{c}$ in the output (figure1, design $\mathrm{j}$ ), by analog with the similar process presented in other subpatterns.

These impulses proceed to:

- the inputs of the initial setting of elements ("Reset") for the temporal selection subpattern of video pulses (figure 3);

- the "Reset" input of the inertial link (figure 4) which forms the impulse in the output as the strobe interval for the transformation of the marked impulses' duration from the given value to the digital in accordance with the controller equation

$$
U_{12}=E_{a d}\left[A_{\partial u \phi_{2}}\left(\tau_{\phi}\right), A_{\partial u \phi_{2}}\left(\tau_{c}\right)\right] .
$$

With the help of the strobe intervals and impulses $\tau_{\phi}$ the digital transformation element of the given intervals (figure 4) forms their digital analogs as $\hat{\tau}_{U}, \hat{T}_{U}, \hat{T}_{k}$ and $\hat{T}_{c}$ in accordance with the controller equation (4). The generator of the formulaic quantities $\left\{\Delta t_{\ni}\right\}$ is being synced by impulses $\tau_{\phi}$ that halves the inaccuracy dispersion from the digitization of the temporal intervals [1]. The defined information that was selected according to the digitization control subpattern by time (figure 4 ) is being stored in the random-access memory (RAM, figure 5) and after that, the search procedure for values $T_{h_{\max }}$ and $\tau_{h_{\min }}$ is being executed. As a result there forms the tensions $U_{\beta_{1}}$ and $U_{\beta_{2}}$ while the appropriate $T_{U_{\max }}$ and $\tau_{h_{\min }}$ proceed to the input of the element that controls the borderline bandwidth frequencies $\Delta F_{o \sigma}^{(r . r+1)}$ of the input filter (figure 2).

The overall structural pattern of the analog and digital transformations is presented in the figure

\begin{tabular}{|c|c|c|c|}
\hline$\underbrace{U_{6}}_{\text {from dig. cont. }}$ & $\begin{array}{l}\text { Random-access memory } \\
\qquad \hat{\tau}_{U}, \hat{T}_{U}, \hat{T}_{\kappa}, \hat{T}_{c} \\
(\mathrm{RAM})\end{array}$ & $\begin{array}{c}\text { Search } \\
\tau_{U_{\min }}, T_{U_{\max }}\end{array}$ & $\begin{array}{c}\text { Analog and digital } \\
\text { transformation } \\
\text { (ADT) }\end{array}$ \\
\hline by $t$ & $\xi[($ & & \\
\hline
\end{tabular}
6 where the quantization procedure by level is being executed by the analog-to-digital converter [6]. 
Figure 5. The subpattern for the adaptive bandwidth control of the analog input filter

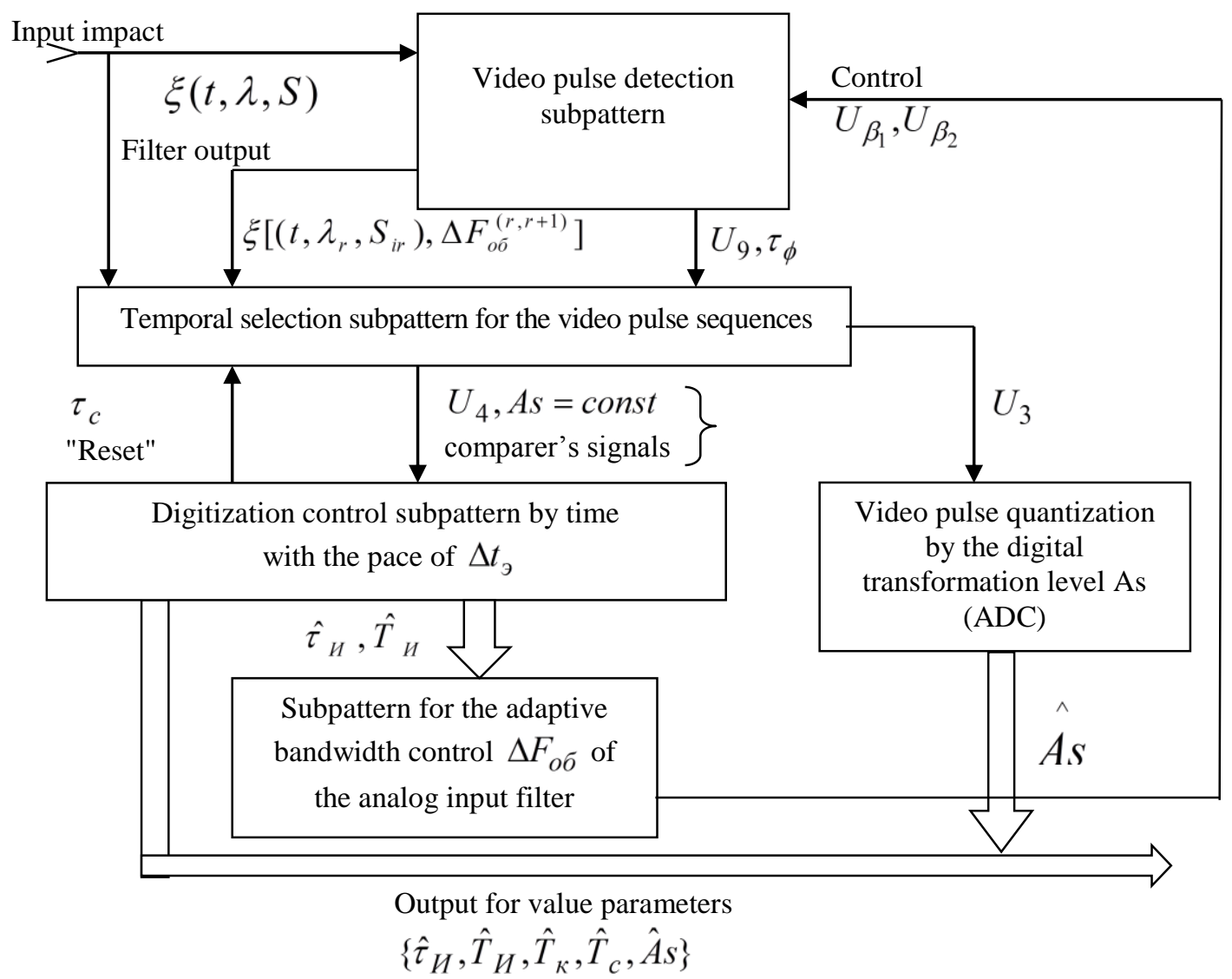

Figure 6. The structural pattern for the analog and digital transformations of the video pulse sequences.

\section{Conclusion}

The formalization of analog and digital transformation processes for the video pulse sequences against the background of additive noise interferences and under predefined uncertainty of the input impact characteristics while using the analytical and structural modeling of these transformations allows to define the methodical approach to composing the functional and structural foundation for the IMS' receiving channel subsystem that will possess an enhanced interference immunity and determination accuracy of the input impact's parameters and characteristics in the present time scale.

\section{References}

1. Burmaka A.A., Govorukhin T.N., Tsyplakov Yu.V., Anikeeva O.A., Mishustin V.N. Optimization of Burmaka A.A., Govoruhina T.N., Cyplakov Ju.V., Anikeeva O.A., Mishustin V.N. Optimizacija analogo-diskretnyh preobrazovanij vhodnogo vozdejstvija v podsisteme priemnogo kanala informacionno-izmeritel'noj sistemy // Avtomatika i telemehanika.

2. Burmaka A.A., Cyplakov Ju.V., Govoruhina T.N. Obnaruzhenie videosignala na fone 
additivnoj shumovoj pomehi pri apriornoj neopredelennosti harakteristik vhodnogo vozdejstvija // Radiotehnika, 2017, №2, s.47-52.

3. Cikin I.A. Diskretno-analogovaja obrabotka signalov // Radio i svjaz, 1982, 160 s.

4. Brjuhanov Ju.A., Lukashevich Ju.A. Vlijanie analogo-cifrovogo preobrazovanija signalov na nelinejnye javlenija v radiopriemnyh ustrojstv // Radiotehnika, 2017, no.2, s.31-35.

5. Burmaka A.A., Cyplakov Ju.V., Govoruhina T.N. Analiticheskaja i strukturnaja modeli prinjatija reshenija $\mathrm{V}$ processe obnaruzhenija posledovatel'nosti videoimpul'sov $\mathrm{s}$ ispol'zovaniem procedury differencirovanija vhodnogo vozdejstvija // Radiotehnika, 2017, no. 10, s.163-168.

6. Lam G. The analog and digital filters, calculation and execution // The world, 1982, $592 \mathrm{p}$.

\section{UOT 621.397}

\section{Burmaka Alexsandr A. ${ }^{1}$, Qovoruxina Tatyana N. ${ }^{2}$, Krupennikov Dmitriy V. ${ }^{3}$}

${ }^{1,2}$ Conub-Qərb Dövlət Universiteti, Kursk, Rusiya

3 "London express" linqvistik məktəbi

1kstu-bmi@yandex.ru, ${ }^{2}$ govtn@mail.ru, ${ }^{3}$ krupen_92@mail.ru

Giriş effektləri xüsusiyyətlərinin aprior qeyri-müəyyənliyi zamanı videoimpulslar ardıcıllığının analoji-diskret və rəqəmli dəyişikliyi modelləri

Faydalı siqnalların və küylərin cəminin qarışığı kimi giriş effektləri şəklində informasiya-ölçü sisteminin (IOOS) girişinə doğru hərəkət edən videosiqnalların analoji-diskret və analoji-rəqəmli dəyişikliklərinin analizi aparılmışdır. Məqalədə real zaman miqyasında siqnalların müvəqqəti və energetika parametrləri haqqında etibarlı ölçü məlumatları əldə etməyə, həmçinin giriş effekti xüsusiyyətləri haqqında aprior qeyri-müəyyənlik şəraitində onların ölçülməsi səhvini minimallaşdırmağa imkan verən İÖS-ün qəbul kanalında siqnalın ilkin emalı üsulları göstərilmişdir. İÖS-ün analoq-rəqəm çevirmələrinin onun qəbul kanalının alt sistemində yaranan qeyri-xətti hadisələrə təsirini azaltmaq üçün İÖS-ün məqsəd funksiyasının müvəqqəti və energetika budaqlarının funksional bölünməsinin məqsədəuyğunluğu əsaslandırılmışdır.

Açar sözlor: analoji-diskret dəyişiklik, videosiqnalların parametrlarinin qiymətlandirilməsi.

\section{УДК 621.397}

Бурмака Александр А. ${ }^{1}$, Говорухина Татьяна Н. ${ }^{2}$, Крупенников Дмитрий В. ${ }^{3}$

$\frac{1,2}{2}$ Юго-Западный государственный университет», Курск, Россия

${ }^{3}$ Лингвистическая школа London Express

1kstu-bmi@yandex.ru, ${ }^{2}$ govtn@mail.ru, ${ }^{3}$ krupen_92@mail.ru

Модели аналого-дискретных и цифровых преобразований последовательности видеоимпулсов при априорной неопределенности характеристик входных воздействий

Проведен анализ аналого-дискретных и аналого-цифровых преобразований видеосигналов, поступающих на вход информационно-измерительной системы (ИИС) в виде входного воздействия как аддитивная смесь полезных сигналов и шумов. В статье показаны способы первичной обработки сигнала в приемном канале ИИС, позволяющие получить достоверную измерительную информацию о временных и энергетических параметрах сигналов в реальном масштабе времени, а также минимизировать погрешность их измерения в условиях априорной неопределенности о свойствах входного воздействия. Обоснована целесообразность функционального разделения временной и энергетической ветвей целевой функции ИИС для снижения влияния их аналого-цифрового преобразования на нелинейные явления, возникающие в подсистеме приемного канала ИИС.

Ключевые слова: аналого-дискретное преобразование, оценивание параметров видеосигналов. 